\title{
Clinical Exacerbation Developing During Treatment of Cutaneous Leishmaniasis: An Id Reaction?
}

\author{
Kutanöz Leishmaniasis Tedavisi Sırasında Oluşan Klinik Alevlenmeler: İd Reaksiyonu mu?
}

\section{Yavuz Yeşilova', Ahmet Özbilgin², Enver Turan'1, Hacer Altın Sürücü', Mustafa Aksoy³}

${ }^{1}$ Harran Üniversitesi Tıp Fakültesi, Dermatoloji Anabilim Dalı, Şanlıurfa, Türkiye

${ }^{2}$ Celala Bayar Üniversitesi, Parazitoloji Anabilim Dalı, Manisa, Türkiye

${ }^{3}$ Özel Orta Doğu Hastanesi, Dermatoloji Kliniği, Şanlıurfa, Türkiye

\section{Dear Editor,}

Clinical exacerbations were found in the patient being monitored in the dermatology clinic, 3 days after the start of systemic sodium stibogluconate treatment for cutaneous leishmaniasis (CL). The patient was the 5-year-old daughter of the first patient, who also had facial CL lesion, and the clinical exacerbation was seen on the 3rd day of treatment (systemic sodium stibogluconate) (Figure 1). This treatment was continued in both patients with the addition of $0.5 \mathrm{mg} / \mathrm{kg}$ prednisolone for 3 days. Rapid clinical recovery was shown in both patients with systemic corticosteroid (Figures 1d and 2d).

Exacerbation of skin lesions during the treatment of bacterial, viral, fungal, and parasitic diseases is evaluated as an id reaction. This id reaction occurs as a result of the cellular reaction in response to the settlement of fragments resulting from fragmentation or toxins of the pathogen organism together with treatment (1). Particularly, in the id reaction created in tinea capitis profunda disease, the inflammatory reaction is known to be reduced with short-term corticosteroid treatment. With this treatment, an evident clinical recovery was shown in our $\mathrm{CL}$ patients. There are previous studies in literature related to the id reaction in CL disease (2-6).

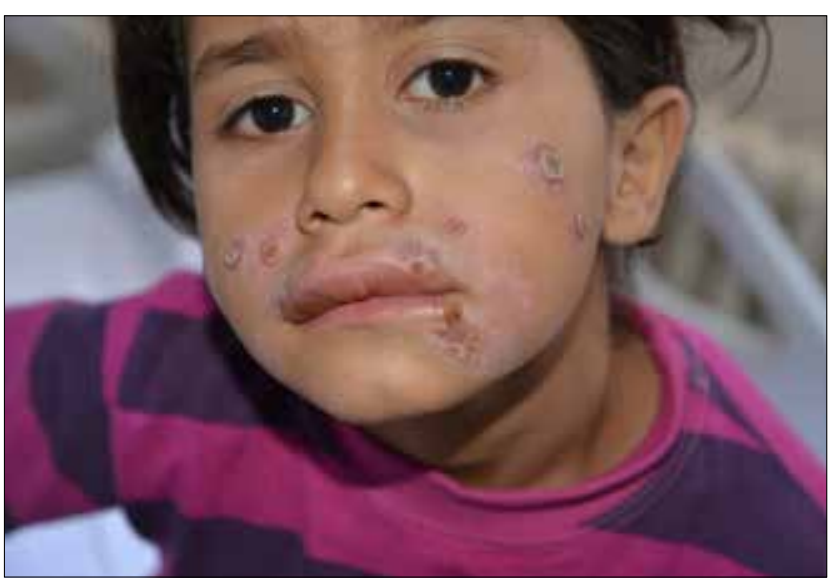

Figure 1. An exacerbation of the cutaneous lesions was seen following systemic sodium stibogluconate treatment

In conclusion, the short-term systemic corticosteroid treatment of clinical exacerbation, which develops during treatment of CL disease, can be useful in achieving a rapid clinical recovery in the patient, increasing the success rate of the cure following treatment, and most importantly, minimizing the potential development of ugly scar tissue.

Address for Correspondence / Yazışma Adresi: Dr. Yavuz Yeşilova, Harran Üniversitesi, Tıp Fakültesi, Dermatoloji Anabilim Dalı, Şanlıurfa, Türkiye. Phone: +90505 5029398 E-mail: yavuzyesilova@gmail.com 


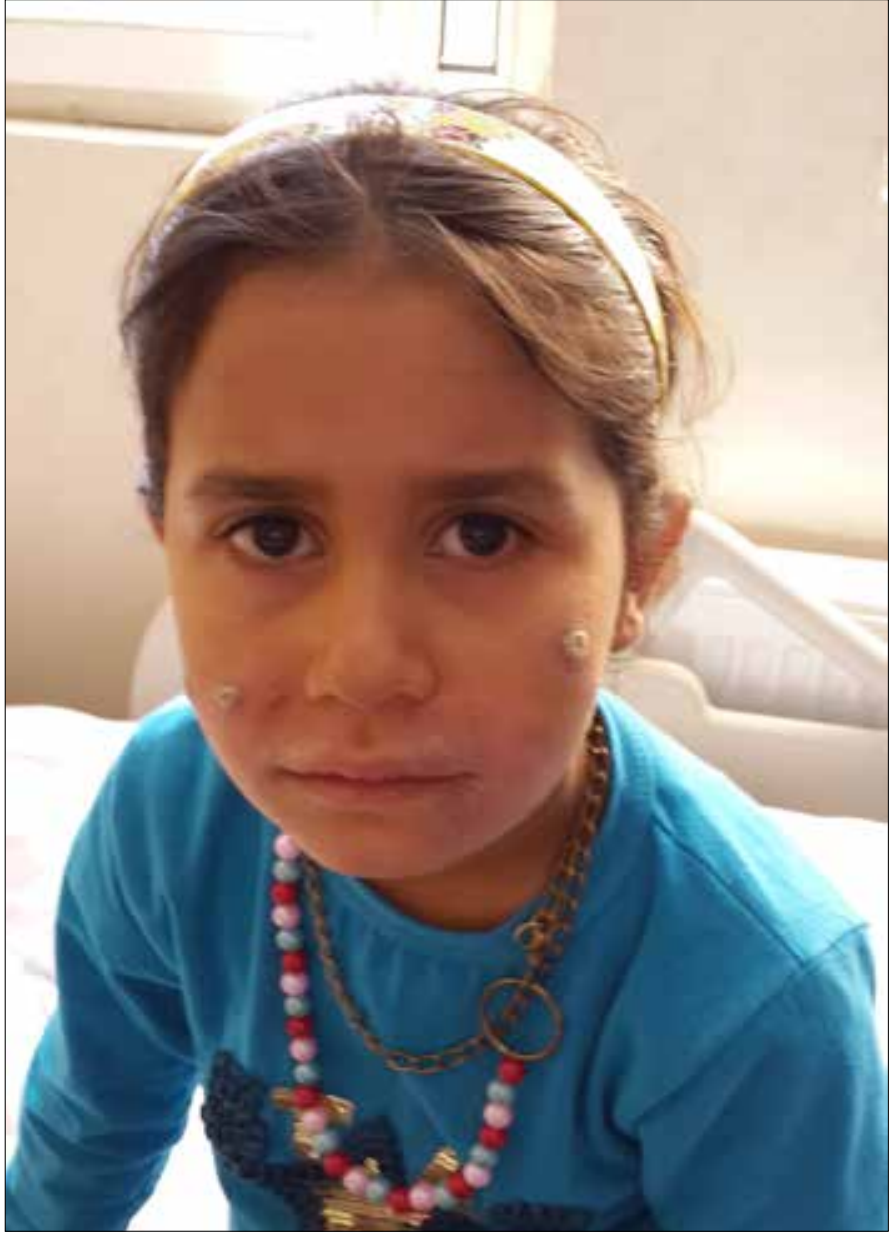

Figure 2. Following Prednol treatment, the cutaneous lesions were seen to recede (an improvement was seen in the cutaneous lesions following Prednol treatment)

In conclusion, the short-term systemic corticosteroid treatment of clinical exacerbation which develops during treatment of CL disease can be useful in achieving a rapid clinical recovery for the patient, in increasing the success rate of the cure following treatment and most importantly, in minimising the potential development of ugly scar tissue.

Ethics Committee Approval: Ethics committee approval was received for this study.
Informed Consent: Written informed consent was obtained from patients who participated in this study.

Peer-review: Externally peer-reviewed.

Author Contributions: Concept - Y.Y., A.Ö., M.A.; Design - E.T., H.A.S.; Supervision - E.T., A.Ö.; Funding - Y.Y.; Materials - Y.Y., M.A., H.A.S.; Data Collection and/or Processing - Y.Y., A.Ö.; Analysis and/ or Interpretation - Y.Y., E.T.; Literature Review - Y.Y.; Writer - Y.Y.; Critical Review - A.Ö., E.T.

Conflict of Interest: No conflict of interest was declared by the authors.

Financial Disclosure: The authors declared that this study has received no financial support.

Etik Kurul Onayı: Bu çalışma için etik komite onayı alınmıştır.

Hasta Onamı: Yazılı hasta onamı bu çalışmaya katılan hastalardan alınmıştır.

Hakem Değerlendirmesi: Dış Bağımsız

Yazar Katkıları: Fikir - Y.Y., A.Ö., M.A.; Tasarım - E.T., H.A.S.; Denetleme - E.T., A.Ö.; Kaynaklar - Y.Y.; Malzemeler - Y.Y., M.A., H.A.S.; Veri Toplanması ve/veya işlemesi - Y.Y., A.Ö.; Analiz ve/veya Yorum - Y.Y., E.T.; Literatür taraması - Y.Y.; Yazıyı Yazan - Y.Y.; Eleştirel inceleme - A.Ö., E.T

Çıkar Çatışması: Yazarlar çıkar çatışması bildirmemişlerdir.

Finansal Destek: Yazarlar bu çalışma için finansal destek almadıklarını beyan etmişlerdir.

\section{REFERENCES}

1. Ilkit M, Durdu M, Karakaş M. Cutaneous id reactions: a comprehensive review of clinical manifestations, epidemiology, etiology, and management. Crit Rev Microbiol 2012; 38: 191-202. [CrossRef]

2. Berlin C, Brenner S. Leishmanid. Isr J Med Sci 1982; 18: 285-6.

3. Chaglassian HT, Farah FS, Kurban AK. The leishmanid. Dermatol Int. 1967; 6: 161-2.[CrossRef]

4. Ramos E Silva J. The concept of leishmanid. Hospital (Rio J) 1959: 55: 883-92.

5. Zuckerman A, Sagher F. Experimental cutaneous leishmaniasis. The development of multiple cutaneous lesions (leishmanid) following the prophylactic inoculation of living Leishmania tropica into a single site. J Invest Dermatol 1963; 40: 193-8.

6. Calı G. Mediterranean cutaneous leishmanid in the adult. Riforma Med 1951; 65: 738-43. 